\title{
"O FILME SERÁ UM ELEMENTO ORIGINAL DA ARTE NEGRA": SOBRE OS FINAIS METAFÓRICOS DOS FILMES AFRICANOS DE FLORA GOMES
}

\author{
Jusciele C A de Oliveira
}

\begin{abstract}
Resumo: No Brasil e em Portugal, ainda há poucos estudos críticos e analíticos sobre culturas africanas, especialmente acerca do cinema de países de língua portuguesa e intelectuais e cineastas africanos e africanas, principalmente quando se aborda a Guiné-Bissau, apesar de este país ter relações próximas com Portugal desde o século $\mathrm{XV}$, momento histórico das navegações europeias e do período colonial; e com o Brasil desde o século XVII, época de intenso tráfico de africanos escravizados. Neste sentido, espera-se contribuir com o alargar de conhecimentos em torno da Guiné-Bissau, nomeadamente por meio da abordagem de obras de ficção cineastas como Flora Gomes: Mortu nega (1988), Udju azul di Yonta (1992), Po di sangui (1996), Nha fala (2002) e Republica di mininus (2012), que em seus filmes apresenta reflexões sobre a sociedade, a história, as memórias e as tradições bissau-guineenses de maneira em nada estereotipada, especialmente, ao que concerne ao início e ao final dos filmes de ficção de Gomes.
\end{abstract}

Palavras-chave: cinemas africanos; cinema da Guiné-Bissau; Flora Gomes.

\section{"THE FILM WILL BE AN ORIGINAL ELEMENT OF BLACK ART": ABOUT THE METAPHORICAL ENDINGS OF FLORA GOMES'S AFRICAN FILMS}

\begin{abstract}
In Brazil and Portugal, there are still few critical and analytical studies on African cultures, especially about the cinema of Portuguese-speaking countries and African and African intellectuals and filmmakers, especially when it comes to Guinea-Bissau, although this country has close relations with Portugal since the fifteenth century, the historical moment of European navigation and the colonial period; and with Brazil since the seventeenth century, a time of intense trafficking of enslaved Africans. In this sense, it is hoped to contribute to the widening of knowledge around Guinea-Bissau, namely through the approach of fiction works by filmmakers such as Flora Gomes: Those Whom Death Refused (1988), Blue eyes fo Yonta (1992), Tree of blond (1996), My voice (2002) and Children republic (2012), who in his films presents reflections on Bissau-Guinean society, history, memories and traditions in no way stereotyped, especially with regard to the beginning and end of Gomes's fiction films.
\end{abstract}

Key-words: african cinemas; cinema of Guinea-Bissau; Flora Gomes.

\section{"LE FILM SERA UN ÉLÉMENT ORIGINAL DE L'ART NÉGRE": À PROPOS DES FINS MÉTAPHORIQUES DES FILMS AFRICAINS DE FLORA GOMES}

Résumé: Au Brésil et au Portugal, il existe encore peu d'études critiques et analytiques sur les cultures africaines, en particulier sur le cinéma des pays de la langue portugaise et des intellectuels et cinéastes africains et africains, en particulier en Guinée-Bissau, bien que ce pays entretienne des relations étroites avec le Portugal depuis le XVe siècle, moment historique de la navigation européenne et de la période coloniale; et avec le Brésil depuis le XVIIe siècle, une

\footnotetext{
${ }^{1}$ Doutora em comunicação, cultura e artes pela Universidade do Algarve/PT. Investigadora e crítica dos cinemas africanos, especialmente da obra do cineasta bissau-guineense Flora Gomes. E-mail: jusciele@gmail.com
} 
période de trafic intense d'Africains esclaves. En ce sens, on espère contribuer à l'élargissement des connaissances autour de la Guinée-Bissau, notamment par l'approche d'œuvres de fiction de cinéastes tels que Flora Gomes: Mort refusée (1988), Les yeux bleus de Yonta (1992), L'Arbre de sang (1996), Ma voix (2002) et La république des enfants (2012), qui présente dans ses films des réflexions sur la société, l'histoire, les mémoires et les traditions bissau-guinéennes, sans aucun stéréotype, en particulier en ce qui concerne le début et la fin des films de fiction de Gomes.

Mots-clés: les cinémas africains; cinéma de Guinée-Bissau; Flora Gomes.

\section{"LA PELÍCULA SERÁ UN ELEMENTO ORIGINAL DEL ARTE NEGRO": SOBRE LOS FINALES METAFÓRICOS DE LAS PELÍCULAS AFRICANAS DE FLORA GOMES}

Resumen: En Brasil y Portugal, hay pocos estudios críticos y analíticos sobre las culturas africanas, especialmente sobre le cine de los países de idioma portugués, e intelectuales y cineastas africanos y africanas, especialmente cuando se trata de Guinea-Bissau, aunque este país tiene relaciones estrechas con Portugal desde el siglo XV, momento histórico de viajes europeos y período colonial; y con Brasil desde el siglo XVII, época de intenso tráfico de africanos esclavizados. En este sentido, se espera contribuir con el extenso de conocimientos en torno a Guinea-Bissau, en particular a través del abordaje de obras de ficción cineastas como Flora Gomes: La muerte negada (1988), Los ojos azules de Yonta (1992), L'árbol de sangre (1996), Mi voz (2002) y La republica de los niños (2012), que en sus películas presenta reflexiones sobre la sociedad, la historia, las memorias y las tradiciones bissau-guineanas de manera en nada estereotipada, especialmente, a lo que concierne al inicio y al final de las películas de ficción de Gomes.

Palabras-clave: cines africanos; cine de Guinea-Bissau; Flora Gomes.

\section{OS CINEMAS AFRICANOS CONTEMPORÂNEOS}

1. Le film transmettra purement et simplesmente les manifestations de l'avie africaine, em les visualisant sans modification dans leur exposition et dans leurs contextures; 2. Le film transposera ces mêmes manifestations, em lesadaptant à l'expression cinématographique sans pourtant réaliser une oeuvre originale; 3 . Le film sera um élément original de l'art nègre [...]. Dans le premier cas, on parlera de reproduction, dans le deuxième cas d'imitation; la valeur artistique particulière n'apparaîtra que dans le troisième cas, quand le cinéma africain créera véritablement son propre humanisme. Ces trois ordres de manifestation du film apparaissent dans tous les cinemas. Le cinéma africain ne fera donc pas exception $^{2}$ (Vieyra, 1975, p. 244).

\footnotetext{
2 1. O filme transmitirá pura e simplesmente as manifestações do advento africano e as visualizará sem modificação em sua exibição e em suas contexturas; 2. O filme transporá essas mesmas manifestações, adaptando-as à expressão cinematográfica sem, no entanto, produzir um trabalho original; 3. O filme será um elemento original da arte negra [...]. No primeiro caso, falaremos de reprodução, no segundo caso de imitação; o valor artístico particular só aparecerá no terceiro caso, quando o cinema africano realmente criar seu próprio humanismo. Estas três ordens de manifestação do filme aparecem em todos os cinemas. O cinema africano não será uma exceção (Vieyra, 1975, p. 244, tradução da autora).
} 
Os cinemas africanos não deveriam se tornar uma exceção, um desvio, mas sim produzir um artefato original da arte negra, que reproduz o valor artístico da obra de arte, como desejava o cineasta e crítico Paulin Soumanou Vieyra no livro Le cinéma africain: des origines à 1973 (1975). A obra em questão, de fato, trata-se de um clássico sobre os cinemas africanos, não só por ser o primeiro livro sobre a temática, mas também por ser escrito por um africano que se propõe a apresentar os cinemas da África numa perspectiva historiográfica de cada país do continente. Visto que o autor destaca nessa publicação os cinemas e os cineastas nacionais de 35 nações africanas, em muito pesa a qualidade didática que ao trabalho confere característica. Entretanto, passados mais de cinquenta anos do lançamento do primeiro longa-metragem de ficção realizado por um africano, em solo africano, da África Negra: La noire de... (1966), de Ousmane Sembène, os filmes africanos continuam com dificuldades de classificação, permanecem diante do inconveniente de se ultrapassar temáticas e críticas limitadoras, estereotipadas e eurocêntricas; de enquadramento teórico, de consolidação de novas estéticas, em consequência de ainda exigirem-se dos cinemas africanos contemporâneos modelos, paradigmas, procedimentos e critérios que estão relacionados com as primeiras produções cinematográficas africanas.

Assim, tornou-se comum dizer que os cinemas africanos seguem procurando seu espaço, seu lugar de fala e de estética, mesmo depois de mais de 60 anos de história. Essas questões estão sobretudo ligadas à questão econômica e estrutural, mas a procura dos cineastas africanos está relacionada com "a forma fílmica adequada à proposta poética de cada cineasta e às exigências do momento e do contexto mundial em que estes cineastas africanos transitam e recebem outras influências" (Bamba, 2014, p. 94). Nesse sentido é que, mesmo destacando-se sempre a questão das múltiplas possibilidades de filmes e cineastas, o pensamento de cada sujeito é único. Os cineastas africanos estão em busca de sua(s) forma(s) fílmica(s), não apenas de financiamento ou estrutura de equipamentos.

Os cinemas africanos promovem ou provocam reflexões sobre os conceitos, temas, problemas, modelos instituídos; sobre produções que fazem com que a criação do "Outro" seja inferior à "Deles" (ou "Nossa"), iniciando um novo período na sua história. "Uma nova modernidade dos cinemas africanos contemporâneos começou a se revelar lá onde menos se esperava: está no uso mais do que criativo e engenhoso da 
tecnologia do vídeo na Nigéria, em Gana e, daqui a pouco, em toda a África" (Bamba, 2009: 189). Sempre lidando com paradigmas que ressaltam características que elegem uns em detrimento de outros, confrontando antigos e novos modelos, aproveitando-se das discussões da contemporaneidade para repensar políticas, estratégias, estéticas, fomentando multiplicidades de possibilidades de contatos, de trânsitos e visões de mundo. Nesse âmbito, há lugar para todos, "Eles", "Nós" e "Outros". "En explorant ainsi les differences et les interactions culturelles, ce nouveau cinema ne cherche pas à résoudre les tensions mais à leur donner un sens. C'est ainsi qu'il contribute à

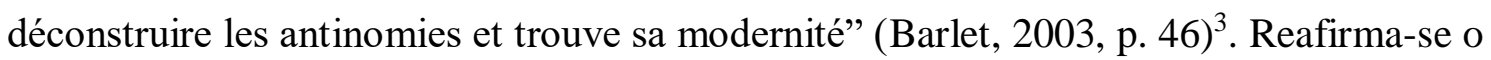
compromisso desse cinema com a diversidade, sem censura de temas ou preferência por gênero cinematográfico. Todavia, sem deixar de lado a preocupação com a questão plural dos cinemas africanos, deve-se pensar especialmente a preciosa experiência dos cineastas:

Today, the movement is toward a multiplicity of voices and cinematic styles that are influenced and inflected by the filmmakers' geographic locations in Africa, Europe or America; the politics of productions, intended audiences, festivals and distributions; and the filmmakers' individual approaches to film language (Diawara, 2010, p. 97) .

Diante da complexidade dos cinemas africanos contemporâneos, há a necessidade de uma análise da temática, da estética, da linguagem cinematográfica peculiar, por vezes autoral dos cineastas, com suas criações marcadas pelo selo dos homens e mulheres que são os autores; pensando suas escolhas individuais, plurais, preferências, inclusive preocupados com novas formas cinematográficas que podem deixar de lado a questão do projeto inicial da construção da nação, em busca de revelar a complexidade do continente, às vezes, até contraditória, autentica, radical, alienada, moderna, (pré; pós; neo)colonial. “Car ce cinéma n’est pas didactique. Il n’a pas la

\footnotetext{
3 "Ao explorar as diferenças e interações culturais, este novo cinema não procura resolver as tensões, mas dar-lhes significado. É assim que contribui para desconstruir as antinomias e encontra sua modernidade " (Barlet, 2003, p. 46, tradução da autora).

${ }^{4}$ Hoje, o movimento é em direção a uma multiplicidade de vozes e estilos cinematográficos que são influenciados e flexionados pelas localizações geográficas dos cineastas na África, Europa ou América; a política de produções, públicos pretendidos, festivais e distribuições; e as abordagens individuais dos cineastas à linguagem cinematográfica (Diawara, 2010, p. 97, tradução da autora).
} 


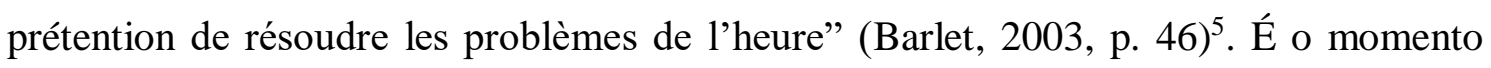
oportuno para a emersão de filmes realizados sem preocupações etnográficas, antropológicas ou exóticas, voltados para um espectador contemporâneo, sedento por novidade, que ainda convive com problemas antigos de financiamento, distribuição e crítica dos filmes africanos.

Para Ferid Boughedir (2007), os cinemas africanos refletem mudanças culturais e sociais que vêm ocorrendo nas nações africanas como consequência de reviravoltas políticas e econômicas que afligem constantemente o continente. Isso quer dizer que os cinemas africanos mostram em suas cenas temas, problemas, questões e reflexões do momento atual de cada país do continente, como também revelam a mudança de postura dos investidores que passaram a investir em cinema produzido por africanos, visto que "o cinema dispõe de uma linguagem ao mesmo tempo sutil e complexa, capaz de transcrever com agilidade e precisão não só os acontecimentos e os comportamentos, mas também os sentimentos e idéias" (Martin, 2003, p. 238).

Desse modo, a questão central e inicial dos temas dos cinemas africanos parece ser o que Ngugi Wa Thiong’o (2007) chama de “descolonizar a imagem” construída pelo espectador e, por vezes, também por quem produz os filmes. Essas imagens (pré)concebidas podem ser distanciadas, quando não distorcidas da representatividade das sociedades, das culturas e dos filmes produzidos e realizados por africanos comprometidos com temáticas africanas, que apresentem as novas estruturas de poder pós-independência, que incluem os sujeitos locais, que por vezes acabam por reproduzir o discurso colonial e neocolonial, já que o filme tem papel fundamental na idealização, construção e na difusão de modelos comportamentais e ideológicos, como destaca Antônio Costa:

O cinema na história: como os filmes podem assumir um papel importante no campo da propaganda política, na difusão ideológica, frequentemente se estabelecem relações muito íntimas entre o cinema e o contexto sócio-político em que se afirma e sobre o qual pode exercer uma influência importante (2003, p. 30).

\footnotetext{
5 "Porque esse cinema não é didático. Não pretende resolver os problemas do momento" (Barlet, 2003, p.46, tradução da autora).
} 
Talvez por isso Flora Gomes, ao conceber seus filmes, pense em realizar películas “definitivamente positivas”, em detrimento dos temas de filmes sobre a África, tais como Hotel Ruanda (2004), O jardineiro fiel (2005), Diamante de sangue (2006) ou $O$ último rei da Escócia (2006), que normalmente estão relacionados com guerras, mortandades étnicas, pessoas morrendo de fome ou por doenças, a exemplo de epidemias vinculadas ao continente, como a AIDS/SIDA, a malária e a cólera. Estes infortúnios são identificados desde os primórdios da fotografia e do cinema ocidental que se preocuparam em retratar o continente africano, especialmente seus habitantes e suas paisagens, por duas linhas de olhares exteriores: um do estranhamento, que explora a representação do outro como exótico, selvagem, espetacularizando o espaço e o Outro, no seu próprio território; e o outro olhar do "afropessimismo" (Diawara, 2010) e da "pornomiséria" (Dias, 2012). Perspectivas ainda exploradas pelos meios de comunicações e pelas agências de turismos, que edificaram também as imagens idílicas e paradisíacas da África para vender safaris e pacotes turísticos.

Essas imagens [fotografias coloniais] acabam em postais e pôsteres que vincavam as aventuras dos exploradores e administradores coloniais, arriscando as vidas pelos projetos europeus de civilização de África. Os olhares eurocêntricos de inúmeros «narradores experientes» e instituições contemporâneas sustentaram as estruturas epistemológicas que continuam a fazer de África um lugar pré-moderno ou um objeto das interpretações ocidentais e imperialistas do progresso (Amkpa, 2012, p. 15).

O poder da imagem e do cinema foi explorado pelo colonizador, inicialmente através das fotografias das viagens dos colonizadores, depois pela realização de reportagens e filmes de cunho etnográfico, como também pela exibição de filmes com os quais se constituíram modelos distantes da realidade africana e imagens estereotipadas sobre a África e o africano que até hoje se relacionam com o continente. Talvez por isso, desde o primeiro contato de um africano com uma câmera de cinema enquanto realizador, houve a preocupação e a responsabilidade deste em torno da representatividade e da auto-representação. Isso em razão de, por muito tempo, só se ter projetado nas telas do mundo a performance do homem negro geralmente como figurante, ou num papel de boy ou de figura cômica impossibilitada de agir ou pensar por si mesma. Já os papéis atribuídos à mulher negra costumam ser secundários e estereotipados. Via de regra, trata-se da emprega doméstica, da mãe preta ou de 
personagens relacionadas com a maternidade, a melhor amiga da protagonista branca, a mulher negra sensual, a hipersexualização do corpo e da sexualidade, a escravizada, além de reproduzir e reforçar o lugar-comum da mulher negra em posição subalternizada, localizada num lugar de dor e sofrimento. $O$ cinema agiu unilateralmente com a África, com o africano e com os homens e as mulheres negras durante longo tempo. O cinema veiculou apenas um retrato do continente e de seus habitantes.

Assim, as preocupações do cineasta africano passam pelo modo como este vê e representa a si próprio, bem como sobre o entendimento de sua obra pelo público, orientado ainda pela responsabilidade de superar imagens depreciativas historicamente produzidas e divulgadas sobre o continente, e a necessidade constante de transformar ou criar novas representações sobre a África, os africanos e suas histórias. Neste sentindo, Flora Gomes não só realiza filmes, ele constrói histórias bem estruturadas, com personagens verdadeiramente construídas psicologicamente, que possuem importância na trama para homens (especialmente mulheres) africanos e negros, que são construídas “diante do espectador, durante o curso da ação, e não apresentado como uma figura mecânica com características determinadas a priori” (Eisenstein, 2002, p. 22). As personagens centrais de Flora Gomes são conscientes politicamente em várias esferas, mas sobremaneira cientes de suas realidades e do seu sistema. "Elas atraem o público porque contam histórias com personagens que estão envolvidas em situações com as quais toda gente consegue se identificar" (Diawara, 2012, p. 21).

Nesse sentido, as argumentações parecem estimuladas pelos contextos cosmopolitas marcados por uma contemporaneidade multifacetada, que se empenha em ainda apagar as dicotomias e as diferenças, em um estágio, em que todos se movimentam, migram, transitam, produzem e consomem culturas em diversos contextos transculturais, transnacionais e transcontinentais, bem como instituem-se novos lugares de reflexões das diferenças, no caso dos cinco longas metragens de ficção do Flora Gomes, apresentando-se possibilidades, para descartar as necessidades das escolhas por uma espécie de lado em detrimento de outro, a ponto de promover a reunião de elementos humanos e culturais em cenários a um só tempo locais e globais (Guiné-Bissau-França-Cabo Verde-Tunísia-Moçambique; África-Europa). 
É que a ideia de contemporaneidade permite também questionamentos, como o provocado pelo poeta, romancista e ensaísta uruguaio Hugo Achugar: "Será necessário revisar, então, as categorias temporais, espaciais, históricas com que nós temos lido?". Achugar deixa a resposta em aberto, na possibilidade de releitura continuada dos estudos produzidos, "também de nossos pensadores, de pensadores e estudiosos como Antonio Cornejo Polar, Angel Rama, Néstor García Canclini e muitos outros mais”. Para ele, "essa é uma tarefa aberta para o futuro" (2006, p.100), na qual agregam-se também brasileiros, portugueses e bissau-guineenses, americanos, europeus e africanos, diaspóricos e sedentários, viajantes, migrantes e residentes; assim como Flora Gomes, entre tantos transculturadores de teorias pelo mundo.

Por isso, utiliza-se "Cinemas africanos", (no plural, para marcar a diversidade cultural implicada), que consiste em expressão que designa produção cinematográfica dirigida precipuamente por africanos e comprometida com temáticas africanas, podendo ou não envolver dispositivos de produção exclusivamente africanos, como sugeriu Paulin Vieyra. Com isso, chamam a atenção o roteiro e o argumento, a cenografia e a preparação de atores e atrizes, estreitamente ligados à figura do diretor, realizador e autor Flora Gomes, de diferentes formas articulando-se com o suporte financeiro da produção, que, contemporaneamente, cada vez mais desloca pessoas isoladas, em favor de empresas transnacionais, transcontinentais e da coparticipação internacional.

\section{A NARRATIVA CINEMATOGRÁFICA DE FLORA GOMES}

Os filmes do realizador bissau-guineense Flora Gomes contam histórias locais com desdobramentos globais, já que falam de trânsitos, de música, de mulher, de crianças, de guerra, de neocolonialismo, de cosmogonia, de vida, de morte, de amor, de nascimento, de migração, de tradição, de modernidade, de coletividade, de política. Seus filmes também tratam de problemas socioeconômicos relacionados com o ecossistema (desmatamento, seca, água). Gomes parece escolher temas concatenados com uma realidade social e cultural local e mundial, mas que se encontram em conflito, em desequilíbrio. Quando expostos ao público, estes temas podem fomentar uma revolução na consciência da mudança individual e coletiva do real. Os títulos de Flora Gomes utilizam como cenário o espaço natural, o ar livre: no meio do mato, na guerra, 
na cidade, no bairro, no deserto, na tabanka, na rua, na praia, seja na África ou na Europa; com discursos irônico, crítico e metafórico, através de diálogos sem muito confronto entre as personagens, mas que possibilitam uma liberdade maior na exploração do texto discursivo, interpretativo e reflexivo.

Nos filmes de Flora Gomes, especificamente ao que corresponde a escrita do roteiro, verificam-se que as ideias originais das películas estão diretamente relacionadas com a memória coletiva, com a cultura, a história da Guiné-Bissau, da África e do Mundo, demonstrando a capacidade e a habilidade do realizador em transformar as experiências de sua vida, do seu espaço, de sua memória individual e coletiva, em arte, em imagem, em filme. A película, cujo título "Mortu nega" (1988) significa, em crioulo bissau-guineense, não só "aquele que a morte negou, rejeitou", mas também algo que está relacionado com a cultura, a história e oralidade da Guiné-Bissau, como explicado por Flora Gomes:

Quando uma mulher dá luz e a criança morre na primeira, na segunda, na terceira ou na quarta vez; a próxima criança que sobrevive recebe o nome de Mortu Nega, que a morte o recusou... Eu utilizei no título, representando os que deviam morrer durante a luta e não morreram, não valem nada, os que sobreviveram que nem a morte os quer, recusou-os (Oliveira; Zenun, 2016, p. 329).

A questão central da trama de Udju azul di Yonta (1992) é a carta na qual consta um poema. A carta foi copiada por Zé de um livro, possivelmente português/europeu, em que são destacadas as características físicas de uma mulher branca, com olhos azuis, bem como fatores climáticos, como neve, que não condizem com os do cenário apresentado pelo filme. Além da problemática que dá título ao filme, o enredo dedica-se a descobrir quem é o admirador de Yonta. Em entrevista ao investigador Nwachukwu Frank Ukadik (2002), Flora Gomes acrescenta que a preocupação também é como se estabeleceram e instituíram os critérios canônicos do que é belo e bom. Nesse momento, esses parâmetros devem ser questionados, modificados, ultrapassados e/ou desconstruídos, para marcar a diversidade política, cultural, artística e estética que contempla o continente africano. De outra maneira, o filme tenta descrever a dinâmica do sistema colonial e neocolonial, também problematizar seus efeitos que perduram na estrutura governamental e na dinâmica social dos estados modernos africanos. 
Po di sangui (1996) encena de forma simbólica e esperançosa o futuro da aldeia e a necessidade de conscientização e a preocupação do porvir do meio ambiente. Pela narrativa final de uma criança, através de desenhos de animais/máquinas antropomorfizadas, somos convidados a pensar no futuro do ecossistema. Um filme de ficção com temática ecológica, inspirado, assim como Mortu nega, na cultura e tradição bissau-guineense: "Há uma raiz animista, de culto pela natureza, e esses tabus ajudam a preservar os locais" (LUSA, 2017). Uma história local e cultural da Guiné-Bissau, mas que ultrapassa as fronteiras territoriais, já que as preocupações com as mudanças climáticas são de responsabilidade mundial, conforme reforça Flora Gomes:

Po di sangui est um regard sur ma société de Guinée Bissau et sur l'Afrique mais c'est aussi um regard extérieur. [...] les arbres sont eux aussi des êtres humains. A la naissance de deux jumeaux, on a plante ces arbres. A la mort de l'um d'entre eux, un des deux arbres meurt. Le sujet est ler apport entre l'homme et son arbre, et donc avec l'ensemble de la nature. Ce n'est pas un film pédagogique mais un regard sur ma société, mon pays (Barlet, 2000, p. 73) ${ }^{6}$.

Já em Nha fala (2002), Flora Gomes criou e encenou uma história que pode bem simbolizar a África, ou seja, o enredo de uma personagem feminina por muito tempo era proibida de se expressar através de sua voz. Sintomaticamente, o realizador nomeia tal personagem como Vita, "vida". Por sua vez, conforme explicitado por Gomes, a expressão "nha fala" significa, ao mesmo tempo, "«minha voz», «meu destino», «minha vida» e «meu caminho»" (cf. Biofilmografia - Notas do realizador, 2002). O enredo de Nha fala centra-se na figura da mulher, embora inicialmente, o cineasta tenha desejado realizar uma história ao redor de um rapaz. Todavia, foi alertado para tratar do feminino, pois, além de poder abordar o direito de autoafirmação, poderia considerar ainda a questão da liberdade de expressão. Serge Zeiton, o produtor do filme, disse em uma entrevista que a metáfora da proibição de cantar lhe parece muito mais forte quando recai sobre a mulher. "Foram elas que foram proibidas de se expressarem" (Ribeiro, 2010).

\footnotetext{
${ }^{6}$ Árvore de sangue é um olhar para a minha comunidade, a Guiné-Bissau e a África, mas também é um olhar de fora. [...] as árvores também são seres humanos. No nascimento de dois gêmeos, plantamos essas árvores. Quando um deles morre, uma das duas árvores morre. $\mathrm{O}$ assunto é a contribuição entre o homem e sua árvore e, portanto, com toda a natureza. Este não é um filme educativo, mas um olhar para minha sociedade, meu país (Barlet, 2000, p.73, tradução da autora).
} 
Neste sentido, cumpre indagar se o título Nha fala reporta exclusivamente à aquisição de voz pela personagem Vita ou se envolve a figura de Amílcar Cabral, uma voz, um discurso cultural que prega uma necessária compatibilidade entre tradição e modernidade. No filme, a herança cultural bissau-guineense, transmitida oralmente, centra-se ainda na história de uma mulher que não pode cantar, reiterando como a força da voz e da palavra. Reforçando sua importância e sacralizando sua força. Uma mulher que para satisfazer o desejo dos seus ancestrais e promover a reconciliação com a tradição percebe: "que para renascer há que aceitar a morte", fala a personagem Vita antes do seu retorno. Estabelecendo a relação com a cosmogonia africana: vida-mortevida, para satisfazer o desejo da tradição, que foi descumprida, ela tem que morrer, mas morrerá uma morte simbólica para renascer mais forte e com seus laços com a tradição mais firmes do que nunca.

No seu último longa-metragem, Republica di mininus (2012), Flora Gomes cria um enredo singular de esperança na construção de um mundo melhor, principalmente para as crianças. Isso por meio da fantasia de uma nação na qual as crianças governam o mundo e não crescem, visto que crescer pode corrompê-las. Conforme indicações iniciais do filme em voz off: “Acontece hoje. Não é em África, mas em todo o mundo. É o fim do mundo, que exige que um mundo melhor seja construído", reiterando que o drama das crianças-soldados, a falta de perspectivas para o futuro das crianças e a violência das guerras podem acontecer em qualquer lugar no mundo, não somente em África. Conforme anuncia, em voz off, a fala da personagem (narrador) Duben (Deny Glover): “Acontece hoje. Não é em África, mas em todo o mundo. É o fim do mundo, que exige que um mundo melhor seja construído". Assim, com a música de Youssou N'Dour em língua Wolof/Uolofe e a voz grave de Duben, somos levados ao mundo da guerra, no qual crianças matam adultos e são sequestradas por adultos, propondo também contar o drama das histórias das crianças-soldados, como do menino Mão-deferro (Hedviges Mamudo) que, após seus pais serem assassinados, se torna uma criançasoldado líder do grupo de sobreviventes que, mesmo tentando fugir da guerra, não consegue; já que carrega uma cicatriz no rosto, que marca não só sua face, mas também sua vida, lembrando-o sempre da sua tragédia pessoal.

Na cidade após o desaparecimento dos adultos, há um outro grupo da república de crianças, liderado pela jovem médica, Nuta (Melanie de Vales Rafael), que 
sobrevivem sozinhos sem orientação e suporte de adultos. Nuta é aconselhada pelo homi-grandi Duben, inclusive, quando o grupo formado por cinco jovens e liderado por Mão-de-ferro cruza o caminho da república de crianças, ele orienta que Nuta aceite-o, mesmo com os problemas causados por Mão-de ferro, o conselheiro insiste que fiquem juntos no mínimo três e no máximo cinco dias, para que tornem-se um único grupo. Embora as crianças tentem ensinar Mão-de-ferro a ser criança, o peso do passado e a cicatriz que carrega na face não conseguem deixá-lo seguir; por isso todos dos grupos unem-se para ajudá-lo e para libertá-lo dos seus próprios medos, realizam um ritual de criança (jogar pedras na água), para livrarem-se das mágoas do passado, para poder viver o presente e pensar no futuro.

\section{“O FIM É O PRINCÍPIO": OS FINAIS METAFÓRICOS DE FLORA GOMES}

Flora Gomes conclui os seus filmes com finais metafóricos, que proporcionam múltiplas leituras e interpretações, abrindo possibilidades de idealizar e até fantasiar a realidade, através de uma festa de casamento (Udju azul di Yonta), pois, segundo o próprio autor: "Poderia dizer mesmo que nunca termino os meus filmes. É como a sequência final do Os Olhos azuis de Yonta. Tratava-se de um sonho, como quando saímos de um casamento, de uma grande festa... sonha-se muito" (FINA, 1995, p. 49). Para Akin Adesokan, por essa razão, “The dilemma that characterizes Gomes's work is best captured in Udju Azul di Yonta, a story of desires that uses cinematic fantasy to articulate the uneasy existence of nationalist aspirations and the material yearnings of the young" (2011, p. 33-34) ${ }^{7}$ (Figura 01).

\footnotetext{
7 "O dilema que caracteriza o trabalho de Gomes é mais bem captado em Udju Azul di Yonta, uma história de desejos que usa a fantasia cinematográfica para articular a existência desconfortável de aspirações nacionalistas e os anseios materiais dos jovens" (Adesokan, 2011, p. 33-34, tradução da autora).
} 
Figura 01. Imagens finais de Udju azul di Yonta

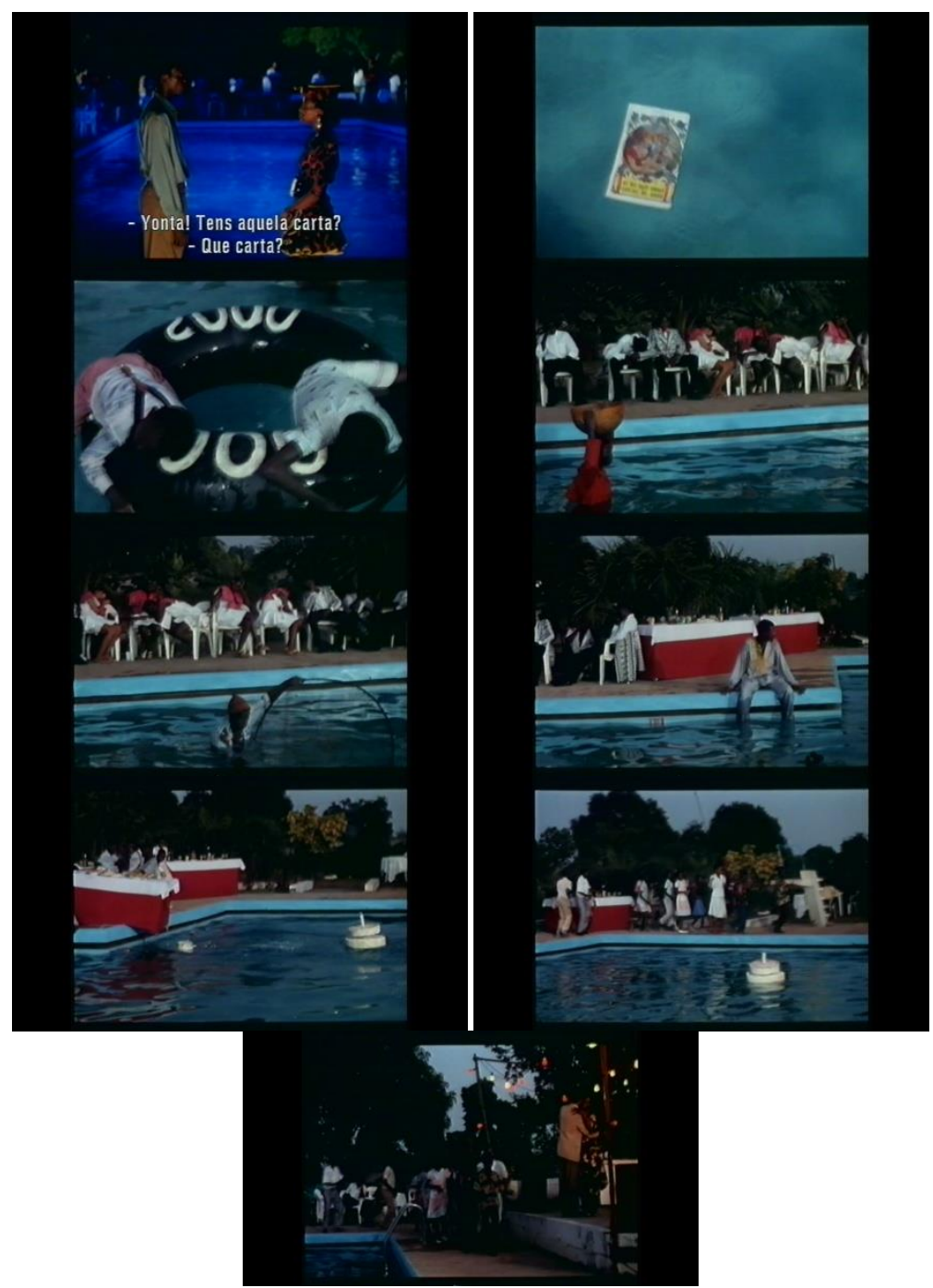

Fonte: (Gomes, 1992)

$\mathrm{Na}$ referida cena final, o livro boia na piscina. As crianças boiam na boia onde está escrito 2000. Algumas pessoas dormem nas cadeiras. Pescadores pescam na piscina. Vicente está sentado na borda da piscina e olha profundamente para a água. A mesa girante derruba comida dentro da piscina. As crianças saem debaixo da mesa e começam a dançar. Yonta também, já com o cinto-relógio ${ }^{8}$ nas mãos, dança. Um casal (Belante e Ambros) dança sozinho. A dança lenta dos dois não faz muito sentido com o ritmo da música que é tocada: um som de tambor, alegre e animado (Figura 01). O filme

\footnotetext{
${ }^{8} \mathrm{O}$ cinto-relógio é um presente de Vicente para Yonta, que trouxe da sua viagem a Portugal, e é mais uma crítica sarcástica à transposição dos modelos, no caso em questão da moda, do acessório, que está destoante das vestimentas e acessórios da moda local.
} 
termina bruscamente, como se não tivesse terminado. Para Akin Adesokan, o gesto de Zé e o final do filme representam uma crítica ao momento pós-colonial de problemas sociais vividos pela Guiné-Bissau; o filme, para tal, utiliza-se da estética e da fantasia do cinema:

This gesture, like the film's ending itself, is aestheticized: in a film so invested in the sociopersonal dimensions of a failing, postcolonial state, Gomes takes pains to pay homage to cinema, to register a set of gestures that transcend the misery of the moment and recover the illusions of spectacular cinema, a lá $\mathrm{La}$ Dolce Vita (2011, p. 44-45) ${ }^{9}$.

David Murphy e Patrick Williams destacam que a cena final é surrealista, mesmo o filme sendo uma "broadly realist narrative framed by moments which are both symbolic and, particularly in the case of the closing scene, quite surrealist. Its brighter colours and use of both pattern and fabric reflect its interest in both youth culture and African culture more broadly" $(2007, \text { p. 134 })^{10}$. É uma narrativa realista e crítica, mas, através da música, das crianças, dos jovens, do cinema, apresenta uma nesga de esperança, desejando que o futuro destes possa ser transformado, sempre em busca de uma Guiné-Bissau consciente, descolonizada e pronta para (re)construir seus modelos.

O final do filme Mortu nega inicia-se com um sonho da personagem Diminga, no qual o fogo destrói tudo. Depois de Diminga narrar o seu sonho às mulheres da tabanka, que ficam horrorizadas, uma mindjer garandi diz que "isto não está bem. Temos que invocar as almas", demonstrando que há uma relação espiritual entre a natureza e o homem bissau-guineense, já que existe a necessidade de realização de uma cerimônia para que a chuva volte a molhar o chão da Guiné-Bissau. É importante evidenciar que, nas ontologias bissau-guineenses, o sonho faz parta da esfera existencial do ser, por meio do qual se estabelece relação com o mundo espiritual (deuses, antepassados e ainda com os que não nasceram). Por isso, a revelação e a interpretação de um sonho, pelos mais velhos, são de significativa importância cultural. Todavia, na

\footnotetext{
${ }^{9}$ Esse gesto, como o próprio final do filme, é estetizado: em um filme que investe nas dimensões sóciopessoais de um estado pós-colonial falido, Gomes se esforça para homenagear o cinema, registrar um conjunto de gestos que transcendem a miséria do momento e recuperar as ilusões do cinema espetacular, a lá La Dolce Vita (Adesokan, 2011, p. 44-45, tradução da autora).

10 "Narrativa amplamente realista estruturada por momentos que são tanto simbólicos quanto, particularmente no caso da cena final, bastante surrealistas. Suas cores mais brilhantes e uso de padrões e tecidos refletem seu interesse tanto na cultura jovem quanto na cultura africana" (Murphy; Williams, 2007, p. 134, tradução da autora).
} 
compreensão ocidental, os sonhos, no cinema, estão relacionados com contos de fadas ou histórias surrealistas e exóticas ${ }^{11}$. Distanciando-se desta visão surrealista, no filme Mortu nega, o sonho da protagonista proporciona a possibilidade de relação com os elementos da vida espiritual da existência dos bissau-guineenses (Figura 02).

\section{Figura 02. Seleção de imagens do sonho de Diminga (Mortu nega)}
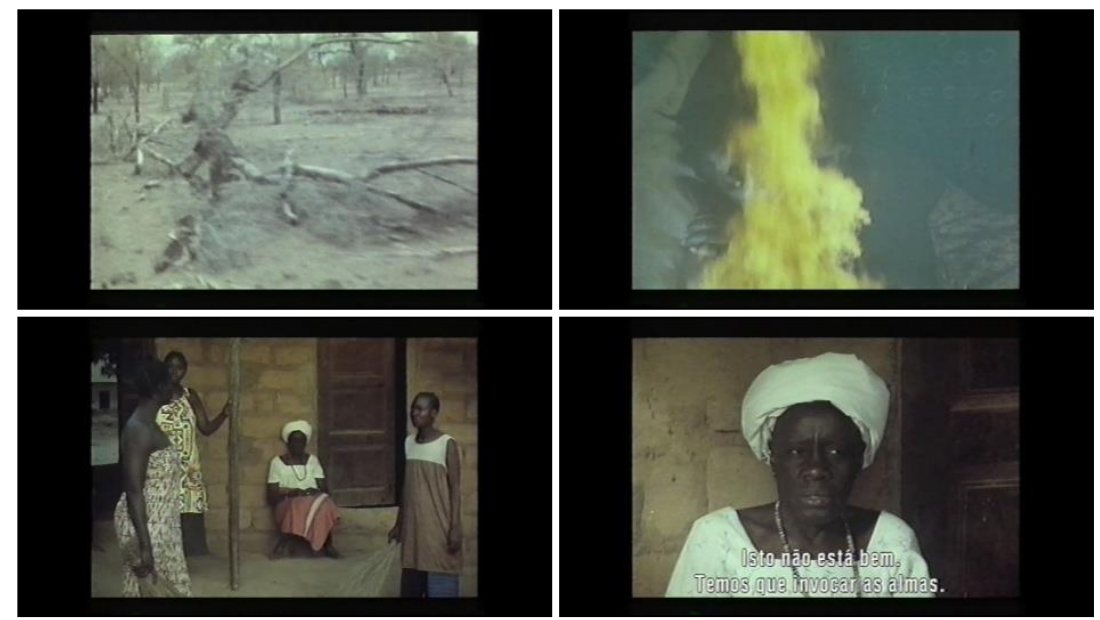

Fonte: (Gomes, 1988).

Para anunciar a realização do ritual de invocação às almas, toca-se Bombolon ${ }^{12}$, promovendo-se assim uma cerimônia de união dos povos da Guiné-Bissau, inclusive dos vivos e dos mortos, para assim tentar explicar os motivos da grande seca que assola a nação bissau-guineense, possivelmente atribuída àqueles que estão desmatando a flora local, como destaca Diminga:

Djon Gago $^{13}$, chamaste-nos a esta cerimônia de mortos e vivos para procurarmos junto contigo o caminho de amanhã. Perante estes velhos, vindo das matas mais longínquas da nossa terra, jura dizer-nos a verdade. Entre toda esta gente à vossa volta, há quem queira matar os nossos poilões, os nossos

\footnotetext{
${ }^{11}$ Dessa questão, excluem-se os postulados de Sigmund Freud defendidos no livro A Interpretação de Sonhos, publicado em 1899, que pressupõe que a essência do sonho é um desejo que fora reprimido durante a infância e que a existência do inconsciente pode revelar grandes mistérios da personalidade humana.

${ }^{12}$ Instrumento cavado num tronco de árvore que tem uma função espiritual, já que é utilizado em cerimônias destinadas à comunicação com as divindades.

${ }^{13}$ Djon Gago é o nome de uma divindade do povo Balanta. Ele é considerado o intermediário entre os homens e os deuses. Os balantas compõem grande parte da população bissau-guineense (27\%), que são também conhecidos por tomarem suas decisões coletivamente, conforme representação fílmica em análise.
} 
bissilions e nosso pau-sangue? Diz-nos quem são (excerto de Mortu Nega, 1988).

A cerimônia Djon Gago, para Akin Adesonkan, é uma criação metafórica motivada pelo momento político que vivia a Guiné-Bissau, que tem como preocupação principal questionar a conjuntura do pós-guerra, em forma de drama, evitando simplificações excessivas do passado e do presente, "especially when these temporal markers are visually represented in elements of tradition (the ancestral dance) and modernity (the melodramatic moment of Estin's betrayal). Gomes is aware of this paradox" (2011, p. 40) ${ }^{14}$. E através do pedido aos irãs (deuses) e da celebração do ritual do "Carnaval" 15 , a chuva cai e na tela vê-se a felicidade das crianças (visto que a exposição da chuva na cena final do filme pode representar a purificação), a superação e a libertação do passado colonial (Figura 03). Para Manthia Diawara, Flora Gomes "draws on Cabral's notion of nacional culture, which transforms traditional rituals into revolutionary praxis, to bring women out of the shadow". Também, "The magic of the scene is such that it leaves no doubt that the gods will comply with Diminga's request" $\left(1992\right.$, p. 156) ${ }^{16}$.

\footnotetext{
14 "Especialmente quando esses marcadores temporais são visualmente representados em elementos de tradição (a dança ancestral) e modernidade (o momento melodramático da traição de Estin). Gomes está ciente desse paradoxo"(Adesokan, 2011, p. 40, tradução da autora).

${ }^{15} \mathrm{O}$ carnaval na Guiné-Bissau é caracterizado principalmente pela apresentação das danças, músicas, línguas, rituais relacionados com a cultura específica de cada grupo étnico, por crianças e adultos. Ressalta-se que a população bissau-guineense é constituída por mais de vinte grupos étnicos. Os grupos percentualmente mais numerosos são: Balanta (27\%), Fula (22\%), Mandinga (12\%), Mandjaco (11\%) e Pepel ou Papel (10\%) (Semedo, 2007).

16 "Baseia-se na noção de cultura nacional de Cabral, que transforma os rituais tradicionais em práticas revolucionárias, para tirar as mulheres da sombra". Também, "A magia da cena é tal que não deixa dúvidas de que os deuses vão cumprir o pedido de Diminga" (Diawara, 1992, p. 156, tradução da autora).
} 
Figura 03. Coletânea de imagens das cenas finais de Mortu nega
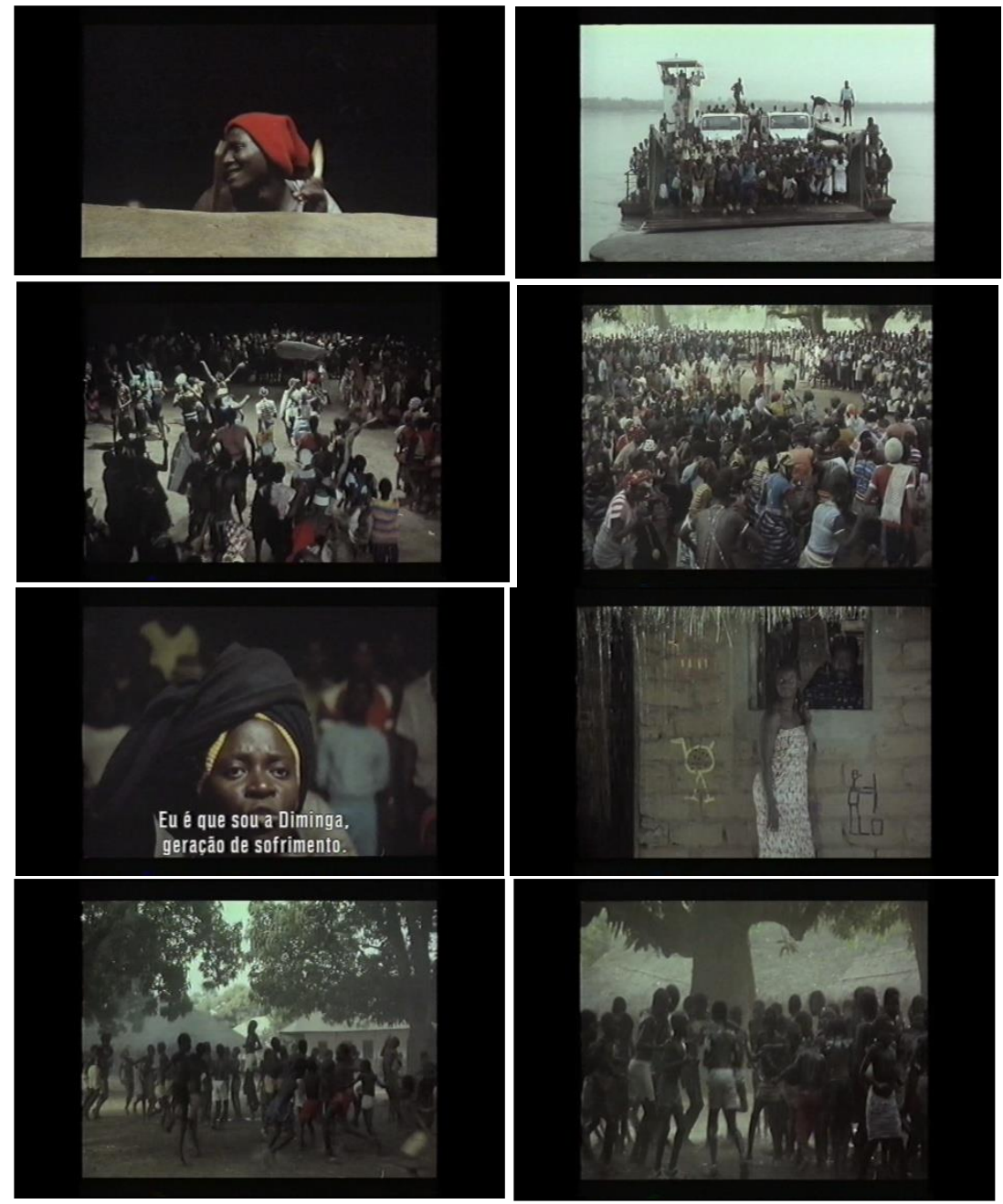

Fonte: (Gomes, 1988)

A partir da fala da personagem Diminga sobre a destruição das árvores de sangue (transcrita anteriormente), pode-se perceber a inspiração para o tema central do filme Po di sangui: os problemas ambientais. Problemas explorados por meio da relação espiritual e cultural entre o homem e a natureza, sobressaindo-se nesse âmbito mais um final metafórico, no qual se destacam a centralidade e a importância da criança e a esperança na construção coletiva de um futuro mais promissor. Na sequência final de $P o$ di sangui, Gomes apresenta na tela um convite para que o espectador participe e seja cúmplice na mudança do futuro das crianças, da natureza, da humanidade para, assim, construírem (o espectador, as crianças e a natureza) um futuro novo, um mundo novo. "Um homem novo, plenamente consciente dos seus direitos e dos seus deveres 
nacionais, continentais, internacionais" (Cabral, 1974, p. 27). Pedido que se consolida pelas imagens (Figura 04), tal qual pelas palavras finais da criança N'tem: “A guerra começou. O sol se irritou muito. Aí, nosso encontro com os de No-Djorson. Eles procuram um mundo melhor, como nós. Eles também são filhos do sol. Agora é preciso plantar muitas árvores!"’ E ainda pelo chamado, através do olhar fixo da criança para a câmera (Figura 04). Esta relação da personagem, ou de Flora Gomes, com o espectador é característica do cinema de autor contemporâneo africano. Conforme destaca Mahomed Bamba, os cineastas inscrevem implicitamente a presença do espectador no filme: "mediante guiños, alusiones a otras películas, con miradas (in)directas y con referencias metafílmicas. En estas películas de autor se crea un efecto de espejo que vuelve a llevar al espectador implícito a la imagen de los otros espectadores vistos en la pantalla $(2015 \text {, p. } 20-21)^{17}$.

\section{Figura 04. Cenas finais de Po di sangui}

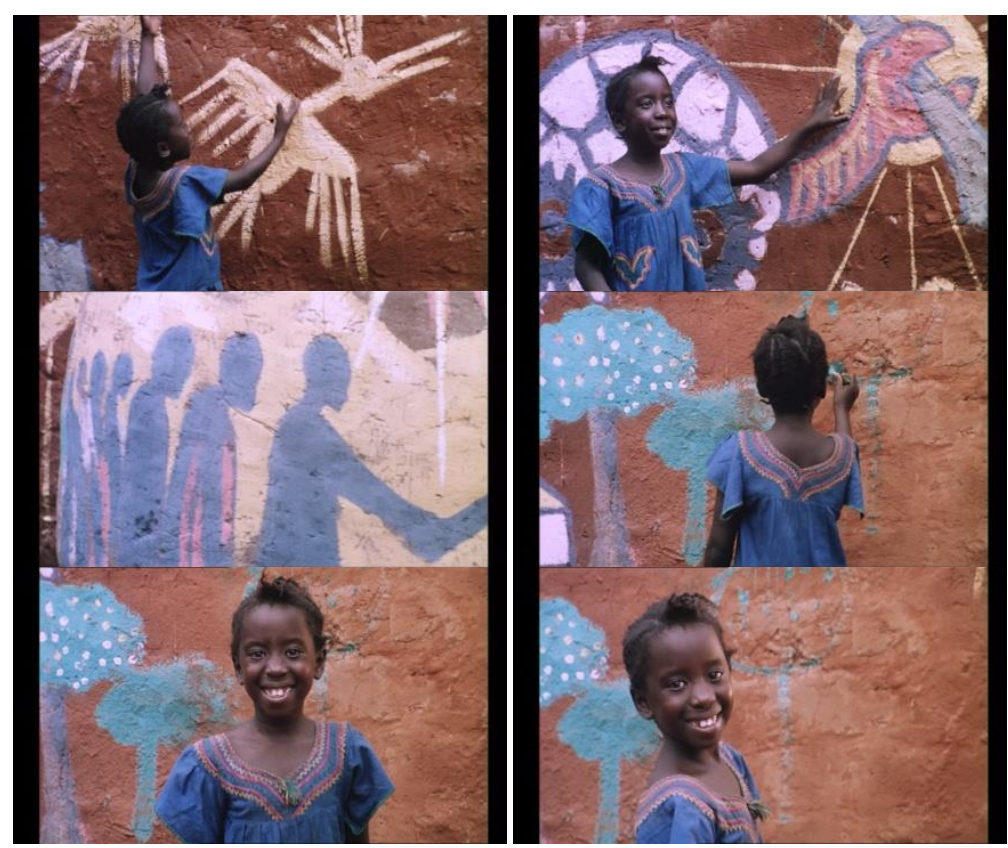

Fonte: (Gomes, 1996).

A metáfora visual ao término de Nha fala explora a estátua/busto de Amílcar Cabral, a qual, na fila para dar os últimos cumprimentos à morta-viva Vita, a

\footnotetext{
17 "Por piscadelas, alusões a outros filmes, com (in) visual direto e com referências metafílmicas. Nos filmes desses autores, cria-se um efeito de espelho que leva o espectador implícito de volta à imagem dos outros espectadores vistos na tela (Bamba, 2015, p. 20-21).
} 
personagem "Louco" passa-a para um homem que a coloca no chão, em um local na rua, e ela fica maior (Figura 05), talvez pelo contato com a terra cabo-verdiana e, por extensão, bissau-guineense. Cabral torna-se o grande homem da Guiné-Bissau e de Cabo Verde, onipresente e autônomo de determinados sujeitos, mas visceralmente vinculado à terra da Guiné. Percebe-se isso quando na cena final encontra-se o local para a estátua de Amílcar Cabral, e ela vai para esse local sozinha, como que a voar, demonstrando-se assim o poder absoluto da representação de Cabral. A estátua, então, dirige-se para uma coluna de pedra - um símbolo administrativo das cidades - tendo ao fundo um lindo pôr do sol.

Figura 05. Estátua de Cabral (Nha fala)

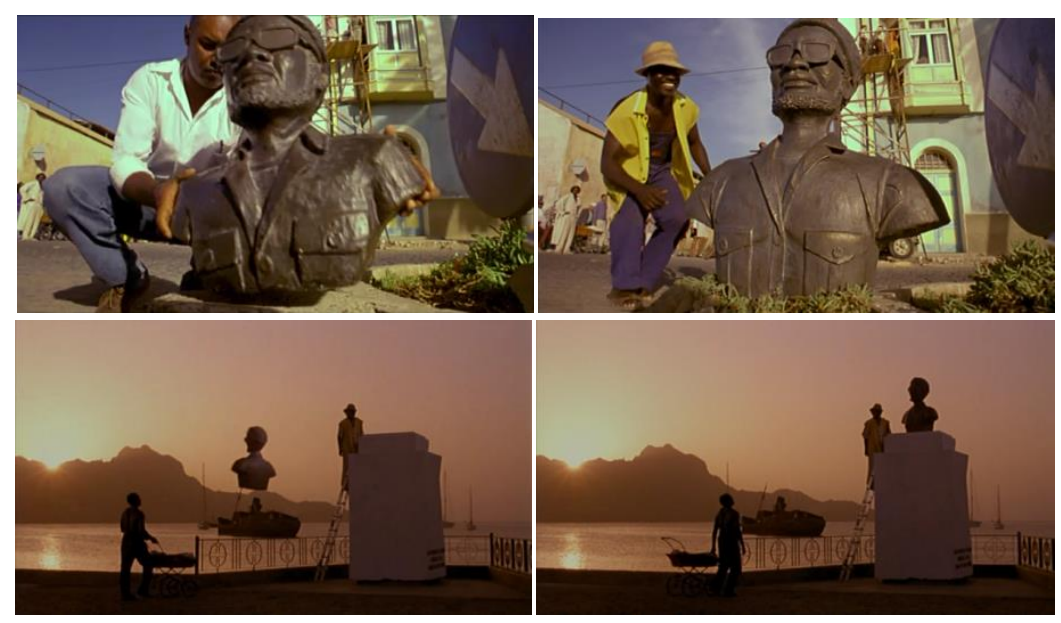

Fonte: (Gomes, 2002).

Nesse momento, a personagem o "Trabalhador" grita pela última vez: "Hoje o céu está limpo!”. E o Louco responde: "Ele disse: o fim é o princípio!”. Os dois dançam e uma pessoa anda de bicicleta para trás, representando a frase enunciada (Figura 06). A intervenção do Louco, no momento final, tem um tom bíblico, levando à reflexão de que a morte não é o fim, mas o início de uma nova vida: trânsitos, circularidades e trocas constantes contemporâneas, em face de parâmetros dissociativos e excludentes; ou alusão a Amílcar Cabral, que, depois da sua morte, imortalizou-se transformando-se em mito e herói africano. 
Figura 06. O final do herói Amílcar Cabral (Nha fala)
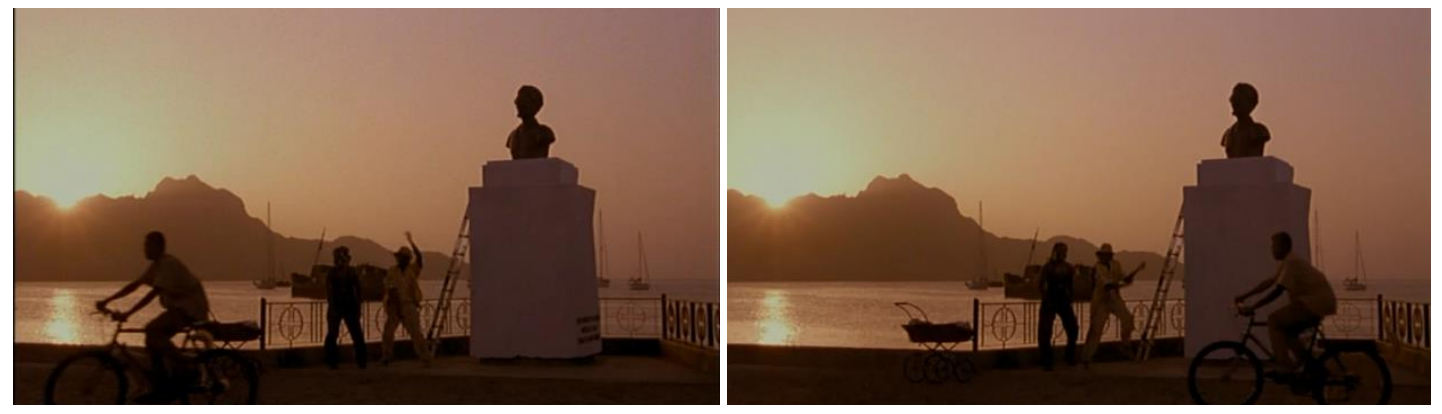

Fonte: (Gomes, 2002).

Mais uma vez, Flora Gomes retoma as componentes presentes no filme Mortu nega. O elemento água será utilizado também um uma das cenas finais do filme Republica di mininus, antes da passagem dos óculos simbólicos de Cabral, quando o jovem Mão-de-ferro realiza um ritual com os membros do grupo para deixar a sua condição e traumas de menino-soldado no passado e ressurgir como um homem novo. O ritual inicia-se com o pedido de Nuta a Dubem para salvar Mão-de-ferro. Após aceitar o encargo da realização do ritual, o homem-grande passa a narrar a cerimônia, enquanto as crianças do grupo de sobreviventes da guerra, liderados por Mão-de-ferro, coletam as pedras (Figura 07):

Pensem em todas as vezes em que magoaram alguém e em que alguém vos magoou. Por cada uma dessas vezes, peguem numa pedra e juntem-na às outras. Façam o que fizerem... levem o tempo que for preciso... e tentem não esquecer ninguém. Vão conseguir finalmente crescer em paz e controlar o vosso destino (excerto de Republica di mininus). 
Figura 07. Seleção de imagens do ritual de libertação de Mão-de-ferro e seu grupo (Republica di mininus)

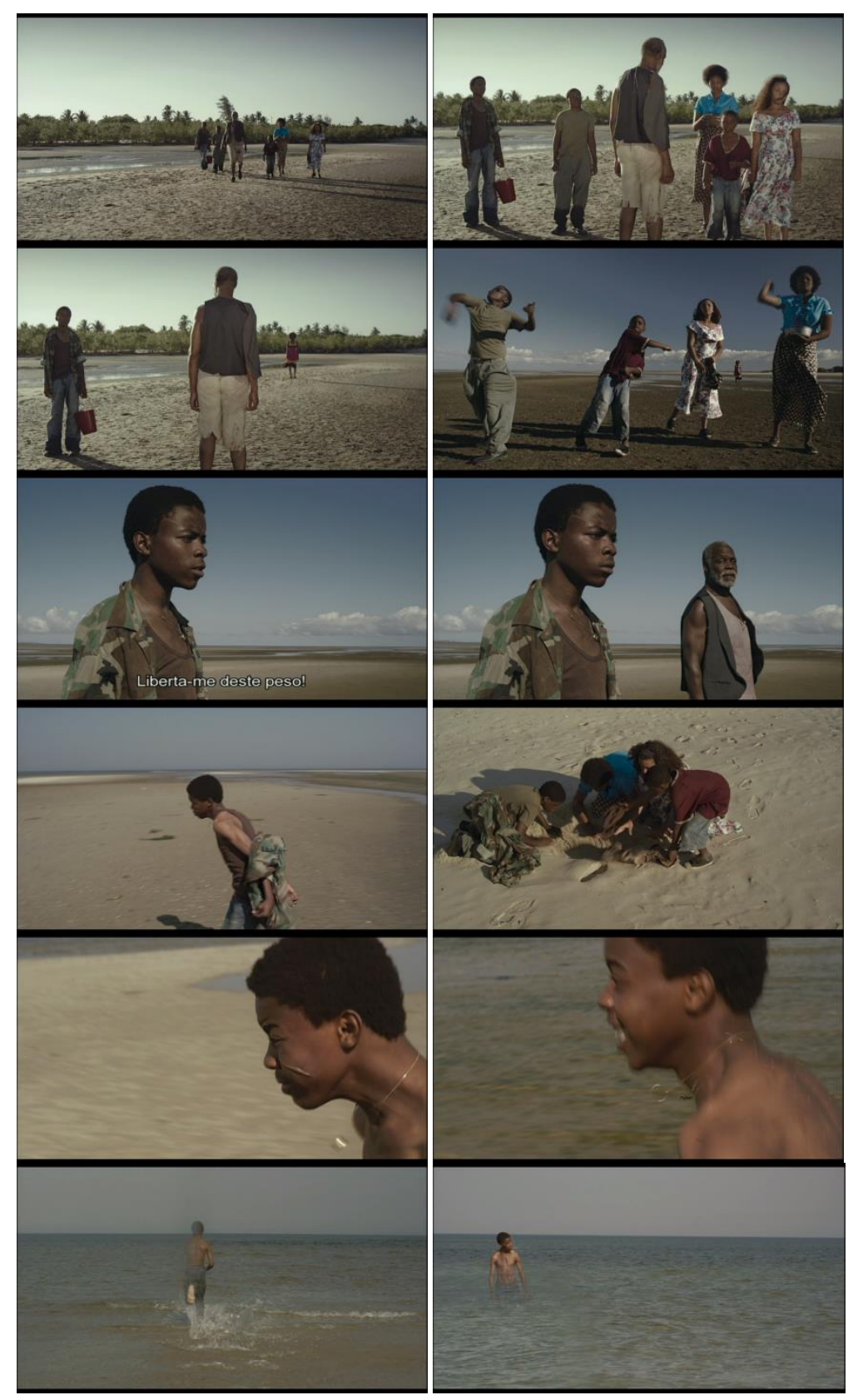




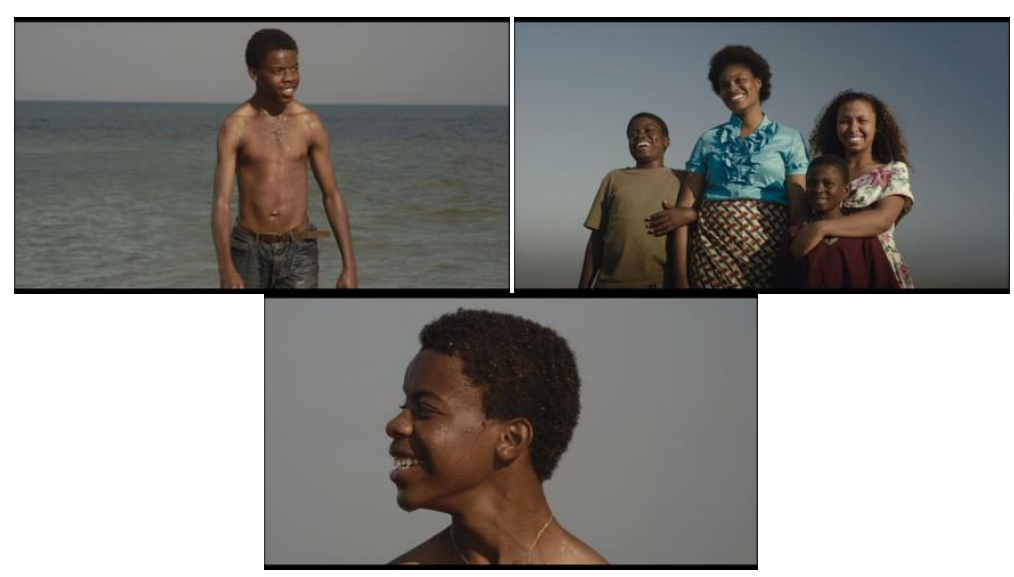

Fonte: (Gomes, 2012).

Depois de recolherem as pedras e da narração ritualística, pela voz grave de Denny Glover em tom profético, juntamente com uma música com ritmo catastrófico e comovente e uma iluminação escura, noturna, elementos que vão acrescentar mais dramaticidade a cena, as crianças lançam as pedras ao mar, sempre orientadas pela sabedoria do idoso e do olhar atento e observador da jovem aprendiz Nuta. Por fim, a criança-soldado roga o seu pedido: "Liberta-me deste peso!". Em tom profético, metafórico e simbólico, Dubem responde: “Todos temos uma pedra no fundo do mar, que guarda os nossos segredos. A história da República das Crianças está gravada nas profundezas". Mão-de-ferro suplica mais uma vez: "Liberta-me! Retira esta mancha! Que a luz negra ilumine meu rosto!” e, assim, joga a última pedra ao mar. A música, através da voz de Youssou N'Dour amplifica-se, agregando mais intensidade à cena, na qual a personagem corre para o mar em busca da sua liberdade. Os companheiros da jornada enterram suas roupas na areia do mar. Na corrida a cicatriz no rosto de Mão-deferro desaparece (Figura 07). A criança-soldado mergulha magicamente no mar e mitologicamente renasce sorridente para a sua nova vida, sem a cicatriz na face, que é a marca e o peso do seu passado, sugerindo que a personagem deixou de lado os medos, as culpas e os traumas, para finalmente viver plenamente o (re)nascimento desse homem novo, ao lado dos seus companheiros.

Os finais metafóricos de Flora Gomes possuem uma estética esotérica e complexas narrativas abertas, que podem ser associadas com filmes produzidos em todo o mundo, e por extensão aos cineastas africanos (Cook, 2013), que contrastam com os filmes hollywoodianos, que dominam o mercado mundial, os quais proporcionam 
sabiamente ao espectador uma fantasia padronizada e em série, com os "roteiros [que] frequentemente incluem idílios ridículos, artificialmente pespegados numa narrativa que só pode terminar no inevitável happy end" (Hennebelle, 1978, p. 46), mas que agradam a "um público cada vez mais condicionado pela uniformização do «espetáculo» audiovisual que lhe é proposto, temos aí um círculo vicioso perfeitamente fechado" (Martin, 2003, p. 248-249).

Assim, com as sequências finais dos filmes de Flora Gomes, é possível perceber a necessidade da conciliação das diferenças através da união dos povos da GuinéBissau, que se juntam para realizar o ritual carnavalesco do Mortu nega; ou pelo encontro geracional dos povos em Udju azul di Yonta, que promovem uma dança coletiva no casamento de Mana; percebe-se isso ainda mediante a cumplicidade entre os povos das tabankas Amanha Lundju e No-Djorson, que simboliza a necessidade do respeito entre os povos; ou na união das crianças para ajudar o menino-soldado Mão-deferro, que precisa ultrapassar o trauma do passado; e nota-se isso também no retorno dos amigos franceses de Vita e dos locais bissau-guineenses, que misturam-se em comemoração ao seu funeral a despeito das diferenças de várias formas refletidas na música final: "Que havemos de fazer/ Para ser ao mesmo tempo iguais e diferentes?/Atreve-te" - uma apologia direta ao momento contemporâneo, no qual as diferenças emergem e podem ser aceitas cultural, econômica e socialmente.

Essas são propostas aparentemente utilizadas por Flora Gomes quando este tenta uma compatibilização e um equilíbrio entre as diferenças culturais ao longo dos filmes, com a junção de dois ou mais elementos diferentes ou contrastantes, sem descredenciamento ou critérios hierárquicos de nenhum dos dois, visto que a contemporaneidade é o momento da complementaridade, onde pode-se existir relações amigáveis entre culturas americanas, africanas, asiáticas e europeias que transitam, por vezes, tranquilamente de uma para outra, visto que não respeitam mais fronteiras.

E para concretizar seu discurso, seu sonho, seu cinema, Flora Gomes acredita no futuro do seu país, do continente africano, das crianças e dos jovens na transformação do mundo, na coletividade e na esperança: "Il faut garder espoir!” (Barlet, 2000, p. $75)^{18}$. Assim, narrando histórias que (des)constroem preconceitos e modelos

18 "É preciso manter a esperança!" (Barlet, 2000, p.75, tradução da autora). 
estereotipados sobre o Outro, sempre destacando a luta pelo futuro das crianças e dos jovens da Guiné-Bissau, da África e do mundo. Como aponta o próprio cineasta, refletindo sobre o seu país de nascimento: “com as cores de esperança e não com as lágrimas das nossas crianças. Nem com os olhos tristes das nossas corajosas mulheres! Tudo na vida tem duas caras. Temos o dia e preparamo-nos para a noite, mesmo que com seu silêncio e as incertezas! No sta djuntu! - Nós estamos juntos” (Oliveira, 2017, p. 173).

\section{CONSIDERAÇÕES FINAIS}

Na medida em que são retratados nos filmes bissau-guineenses, africanos, franceses, portugueses, brancos e negros, adultos e jovens, homens e mulheres, que representam os interesses da comunidade tradicional, da contemporaneidade, do capitalismo transnacional, das donas de casa, dos homens desempregados, da preocupação com o futuro dos jovens, das cerimônias de casamento, funeral e crianças que brincam, por meio de temáticas, histórias e gêneros cinematográficos diversos, Flora Gomes reforça a obrigação de desestruturar, deslocar, repensar, descolonizar o debate sobre a África e os Cinemas Africanos, utilizando o cinema como forma para expor as injustiças locais, continentais e mundiais, mas evitando partidarismos, posicionamentos e perspectivas estreitamente políticos e prévios - o que só é possível por intermédio da arte e do cinema como estratégias ficcionais de criação, de novas possibilidades, novos mundos e novas estéticas. Expondo-se assim estéticas cinematografias africanas que expressam o curso da vida, ou seja, o cotidiano através de personagens, ritmos, movimentos, cenários, iluminação, angulações que prezam pela forma e profundidade constitutivas da narrativa.

Afinal, é na contemporaneidade que o cineasta Flora Gomes exerce o direito da liberdade criadora, nos seus filmes, que não aleatoriamente são dedicados aos seus amigos, as crianças do seu país, à memória de Amílcar Cabral e aqueles a quem não foram dado voz, e que apresentam o imaginário, a visão de mundo africana, por meio do poder da palavra, da imagem e da transgressão dos limites, das relações familiares, do local e do global, das relações entre vida e morte, por meio das cerimônias fúnebres, viagens iniciáticas e ritos de renascimentos como metáforas para a vida social, bem 
como as relações entre a modernidade e tradições, em termos de complementaridade, enfocando como é possível, ao mesmo tempo, "ser iguais e diferentes", consciente, o realizador, de que "entre os países do sul e do norte, entre os países quentes e frios, nada é simples", mas é preciso atrever-se, "ousar", e dar um "bye-bye ao século XX" (Trechos das letras das músicas do filme Nha fala), que empreende e provoca fina reflexão acerca da contemporaneidade, na qual os sujeitos buscam o respeito pela diferença e por serem semelhantes, iguais e diferentes.

\section{REFERÊNCIAS}

Achugar, Hugo. Planetas sem boca: escritos efêmeros sobre arte, cultura e literatura. Trad. de Lyslei Nascimento. Belo Horizonte: Editora UFMG, 2006.

ADESOKAN, Akin. Flora Gomes, filmmaker in search of a nation. Black Camera. In. International Film Journal, v. 3, n. 1, 2011, p. 31-53.

BAMBA, Mahomed. Que modernidade para os cinemas africanos?. In. Catálogo do FórumDoc.BH. $13^{\circ}$ Festival do Filme Etnográfico; Fórum de Antropologia Cinema e Vídeo. Belo Horizonte: Filmes de Quintal, 2009, p.183-190.

BAMBA, Mahomed. A 'irrupção do Outro’ no campo do discurso teórico sobre os cinemas póscoloniais africanos. In. OLIVEIRA, Marinyze Prates de; PEREIRA, Maurício dos Santos; CARRASCOSA, Denise (orgs.). Cartografias da subalternidade: diálogos no eixo sul-sul. Salvador: EDUFBA, 2014, p.77-97.

BAMBA, Mahomed. Reflexión sobre la dimensión espectatorial de las películas africanas: o cómo los cines africanos piensan de otra manera en sus públicos. In. Secuencias. n.41, primer semestre 2015, p.19-40.

BARLET, Olivier. Cinémas lusophones: le gâchis et l'espoir. Africultures. In. "Afriques lusophones". Paris: Edtions L'Harmattan, n.26, mars 2000, p.18-23.

BARLET, Olivier. "Nous coupons une partie de nous-mêmes pour la vendre": entretien avec Flroa Gomes, cinéaste. In. Africultures: "Afriques lusophones". Paris: Edtions L'Harmattan, n.26, mars 2000B, p.73-75.

BARLET, Olivier. Les nouveaux films d'Afrique sont-ils africains?. In. CinémAction: Cinémas africains, une oásis dans le désert?, Saint-Denis, n. 106, $1^{\circ}$ trimester, 2003, p. 43-49.

BOUGHEDIR, Ferid. O cinema africano e a ideologia: tendências e evolução. In: MELEIRO, Alessandra (org). Cinema no mundo: indústria, política e mercado: África. São Paulo: Escrituras, 2007, p.37-56.

CABRAL, Amílcar. Guiné-Bissau: nação africana forjada na luta. Trad. Manuel L. Martins. Lisboa: Nova Aurora, 1974. (Textos Amílcar Cabral, n.1).

COOK, Paul (2013). A importância de um "s": o leeds centre for word cinemas, transnacionalismo, policentrismo e o desafio de Hollywood. In. DENNISON, Stephanie (org.). 
World cinema: as novas cartografias do cinema mundial. Campinas/SP: Papirus, 2013, p.13-34. (Série de Estudos Socine).

COSTA, Antonio. Compreender o cinema. Trad. Nelson Moulin Louzada. 3.ed. São Paulo: Globo, 2003.

DIAS, José António Fernandes. Ver-se e dar-se a ver. In. AMKPA, Awam (org). Catálogo África see you see me!: influências africanas na fotografia contemporânea. Portugal: Sextante Editora, 2012, p. 07.

DIAWARA, Manthia. African film: new forms of aesthetecs and politics. Munich; Berlim; London; New York: Prestel Verlag; Haus der Kulturen der Welt; Prestel Publishing Ltd.; Prestel Publishing, 2010.

DIAWARA, Manthia. Autorrepresentação na fotografia e no cinema africanos. In. AMKPA, Awam (org). Catálogo África see you see me!: influências africanas na fotografia contemporânea. Portugal: Sextante Editora, 2012, p. 18-22.

EISENSTEIN, Sergei. O sentido do filme. trad. Teresa Ottoni. Rio de Janeiro: Jorge Zahar Ed., 2002.

FINA, Cristina. Entrevista com Flora Gomes. In: Cinemas de África - Catálogo. Lisboa: Cinemateca Portuguesa; Culturgest, 1995, p.44-49.

GOMES, Flora (dir.). Mortu nega (Morte negada). [Filme]. Direção de Flora Gomes, produção Instituto Nacional de Cinema da Guiné-Bissau: Guiné-Bissau, 1988.

GOMES, Flora (dir.); SOUSA, Paulo de (prod.). Udju azul di Yonta (Olhos azuis de Yonta). [Filme]. Direção de Flora Gomes, produção executiva de Paulo de Sousa. Bissau, Vermedia, com co-produção de Arco-Íris (Guiné-Bissau), Euro Creation Production (Paris), 1992.

GOMES, Flora (dir.); GALLEPE, Jean-Pierre (prod.). Po di sangui (Pau de sangue). [Filme]. Direção de Flora Gomes. Produção de Arco Íris, SP Filmes, Films Sans Frontières e Cinetelfilm. Roteiro: Flora Gomes e Anita Fernandez. Guiné-Bissau, Portugal, França e Tunísia. DVD, 1996.

GOMES, Flora (dir.); TELES, Luís Galvão; THILTGES, Jani \& ZEITOUN, Serge (prod.). Nha fala (Minha fala). [Filme]. Direção de Flora Gomes, produção de Luís Galvão Teles, Jani Thiltges, Serge Zeitoun. Roteiro: Flora Gomes. Luxemburgo, Fado Filmes - Portugal, Les Films de Mai -França, Samsa Films, DVD, 2002.

GOMES, Flora (dir.); ARTEMARE, François (prod.); MAYER, Maria João (prod.). Republica di mininus (República de meninos). [Filme]. Direção de Flora Gomes. Roteiro: Flora Gomes, Franck Moisnard. Les films de l'Après-Midi; Filmes do Tejo. Guiné-Bissau, Moçambique, França e Portugal. DVD, 2012.

HENNEBELLE, Guy. Os cinemas nacionais contra Hollywood. Trad. Paulo Vidal; Julieta Viriato de Medeiros. Rio de Janeiro: Paz e Terra, 1978.

LUSA. Aldeias da Guiné acreditam nos espíritos da floresta e isso protege o ambiente. Publicado em 11 de fevereiro de 2017. Disponível em: 
$<$ https://www.rtp.pt/noticias/cultura/aldeias-da-guine-acreditam-nos-espiritos-da-floresta-e-issoprotege-o-ambiente_n982298>. Acessado em: 20 fev 2017.

MARTIN, Marcel. A linguagem cinematográfica. Trad. Paulo Neves. São Paulo: Brasiliense, 2003.

MURPHY, David; WILLIAMS, Patrick. Postcolonial african cinema: ten directors. Manchester and New York: Manchester University Press, 2007.

OLIVEIRA, Jusciele. "Epa, meu futuro fica a cada dia Mais incerto": perspectivas de futuro através da trilha sonora e do discurso da criança nas representações pós-coloniais do Filme Os olhos azuis de Yonta (1992), de Flora Gomes. In. Revista Mulemba. Rio de Janeiro: UFRJ, v.9, n.17, jul/dez, 2017, p. 160-176.

OLIVEIRA, Jusciele. "Precisamos vestirmo-nos com a luz negra": uma análise autoral nos cinemas africanos - o caso Flora Gomes. (TESE). Faro/PT: Centro de Investigação em Artes e Cultura, da Universidade do Algarve - CIAC-UALG, 2018.

OLIVEIRA, Jusciele; ZENUN, Maíra. A poesia universal no cinema de um homem africano: entrevista com Flora Gomes. In. Cerrados - Revista do programa de pós-graduação em literatura. n. 41, 2016, p.320-329.[ Áfricas em movimento].

RIBEIRO, Giselle Rodrigues. Nha fala, uma festa do tradicional com o moderno. In. Revista África e Africanidades, Rio de Janeiro, ano 3, n. 9, mai. 2010. Disponível em: <http://www.africaeafricanidades.com/documentos/Nha_fala.pdf >. Acessado em: 3 mai 2010.

SEMEDO, Odete Costa. Guiné-Bissau, Mulheres e Letras. Vozes femininas... por detrás dos escritos. In: III Encontro de Professores das Literaturas Africanas - Pensando África: crítica, pesquisa e ensino, realizado pela UFRJ, UFF e Fundação Biblioteca Nacional, Rio de Janeiro, 21, 22 e 23 novembro 2007.

THIONG'O, Ngugi Wa. A descolonização da mente é um pré-requesito para a prática criativa do cinema africano?. In. MELEIRO, Alessandra (org). Cinema no mundo: indústria, política e mercado: África. São Paulo: Escrituras Editora, 2007, p.27-32.

UKADIKE, Nwachukwu Frank. Questioning african cinema: conversations with filmmakers. Minneapolis: University of Minnesota Press, 2002.

VIEYRA, Paulin Soumanou. Le cinéma africain: des origines à 1973. Paris: Editions Présence Africaine, 1975. Tome I. 